This item was submitted to Loughborough's Research Repository by the author.

Items in Figshare are protected by copyright, with all rights reserved, unless otherwise indicated.

\title{
The 'third gender' in Afghanistan: A feminist account of hybridity as a gendered experience
}

PLEASE CITE THE PUBLISHED VERSION

https://doi.org/10.1080/21647259.2019.1588455

\section{PUBLISHER}

(c) Taylor \& Francis

\section{VERSION}

AM (Accepted Manuscript)

\section{PUBLISHER STATEMENT}

This is an Accepted Manuscript of an article published by Taylor \& Francis in Peacebuilding on 25 Mar 2019, available online: https://doi.org/10.1080/21647259.2019.1588455

\section{LICENCE}

CC BY-NC-ND 4.0

\section{REPOSITORY RECORD}

Partis-Jennings, Hannah. 2019. "The 'third Gender' in Afghanistan: A Feminist Account of Hybridity as a Gendered Experience”. figshare. https://hdl.handle.net/2134/37432. 


\title{
The 'Third Gender' in Afghanistan: A Feminist Account of Hybridity as a Gendered
}

\section{Experience}

\begin{abstract}
This article explores the manifestation of the critical peace studies concepts hybridity and friction in Afghanistan from a feminist perspective. It focuses on female international humanitarian actors, their use of the term 'third gender' to describe their perceived position, and their experiences of performing their gender in hybridised ways. Using original interview data, it argues that the particularly gendered experiences of these actors are key to recognising the gendered nature of peacebuilding and the intersections between feminist approaches and critical peace concepts.
\end{abstract}

\section{Keywords}

Hybridity, Friction, Afghanistan, Third Gender, Feminism, Peacebuilding.

\section{Introduction}

The purpose of this article is to explore the manifestation of the critical peace studies (CPS) concepts hybridity and friction in Afghanistan from a feminist perspective. It will do so by focusing on female international humanitarian actors, ${ }^{1}$ their use of the term 'third gender' to describe their perceived position and their experiences of performing their gender in hybridised ways. While the focus on international humanitarian actors as sites of hybridity and friction in-and-of themselves is unusual and under-theorised, I maintain that they are key to understanding how hybridity and friction function in gendered ways in conflict-affected contexts such as Afghanistan.

As Róisín Read outlines:

\footnotetext{
${ }^{1}$ I use this term loosely to encompass a range of international civil society actors who participate in what are understood to be peacebuilding activities - for instance aid and development work, education and security sector reform, institutional capacity-building. These individuals mostly work for NGOs, international organisations, or big donor entities. I refer to them in this paper as internationals for simplicity, though I am aware that this category of person is expansive and varied.
} 
Humanitarians, especially in conflict-affected areas, increasingly serve as sources of information about the areas they work in and the people they work with; as such, it is important to critically interrogate their experiences and knowledge. ${ }^{2}$

The particularly gendered experience of these actors is key to recognising the gendered nature of peacebuilding and the intersections between feminist approaches and CPS concepts. In this article, like Read, I am interested in how female internationals are marked by and articulate for themselves, specific kinds of difference, and how this 'difference is always embodied and is imbued with meanings, regardless of the degree to which there is conscious awareness of these meanings' ${ }^{3}$ Like McLeod, I am interested in the ways that feminist thinking intersects with and enhances the analytical scope of hybridity by centring on the significance of the 'personal' amongst international actors and paying attention to peace and post-conflict labour as lived experience. ${ }^{4}$

In the context of peacebuilding, hybridity is a 'meeting between international and local norms, actors and practices' creating 'new arrangements, which display hybrid features where for instance liberal and illiberal norms co-exist'. ${ }^{5}$ Following this, I am exploring the 'third gender' as term for female internationals who, in their own perception, combine female bodies and 'liberal' gender expectations with traits, access and behaviour associated strongly with masculinity in 'illiberal' Afghanistan. In the coming together of two apparently divergent sets of gender norms, a new gender arrangement forms as the 'third gender', socio-culturally rather than biologically. I argue that the 'third gender' acts as a hybrid identification framework in everyday praxis, symptomatic of the liberal peace paradigm in Afghanistan in which 'international' and 'local' norms interact. ${ }^{6}$ This interaction creates friction movement back and forth between paradigms, ideas and expectations ${ }^{7}$ - demonstrating the coming

\footnotetext{
${ }^{2}$ Róisín Read, 'Embodying Difference : Reading Gender in Women's Memoirs of Humanitarianism,' Journal of Intervention and Statebuilding Online First (2018), 2

${ }^{3}$ Ibid., 2

${ }^{4}$ Laura McLeod, 'A Feminist Approach to Hybridity: Understanding Local and International Interactions in Producing Post-Conflict Gender Security,' Journal of Intervention and Statebuilding 9, no. 1 (2015): 48-69. ${ }^{5}$ Annika Björkdahl and Kristine Höglund, 'Precarious Peacebuilding : Friction in Global - Local Encounters,' Peacebuilding 1, no. 3 (2013), 290.

${ }^{6}$ For a critique of the idea of the 'local' and this binary in CPS see Nick Lemay-Hebert and Stephanie Kappler's article in this issue.

${ }^{7}$ Ibid.,
} 
together of the 'international' and the 'local', mixing different perceptions and performances of social orders and creating a kind of hybridity with aspects of both.

Afghanistan was the site of global 'war on terror' military intervention in 2001 and a subsequent liberal peacebuilding project running alongside on-going military activity which incorporated a vast array of international and non-governmental organisations (IOs and NGOs), institutions and donors. Broadly speaking Afghanistan has been understood as a classically patriarchal country ${ }^{8}$ meaning that women face unequal treatment in the legal system, education system, governance and security structures and within socio-cultural norms. ${ }^{9}$ As such women's rights and freedoms were a key focus in the liberal peace project, and a key site of politicisation by multiple actors including Afghan political elites, donors and intervening states. ${ }^{10}$ The idea of Afghanistan as a context in which a problematic gender order, particularly patriarchal treatment of women, was pervasive, forms an important backdrop to my exploration of the 'third gender' in this article. Moreover while 'gender' in peacebuilding, donor programming and international institutions, in Afghanistan and more generally, is a key consideration and site of study, few scholars have explored the gender dynamics of the actors that undertake peacebuilding labour and occupy humanitarian spaces. This means that the operation of gender within the everyday praxis and experience of peacebuilding is under-theorised and despite the compatibility of feminist thought with critical peace scholarship, ${ }^{11}$ the latter does not sufficiently envisage the centrality of gender as an organising principle in post-conflict lifeworlds. Equally, a criticism levelled at CPS is that it tends to homogenise the actors it discusses - 'locals' or 'internationals' for example ${ }^{12}$ - and paying attention to the complex gender dynamics within

\footnotetext{
${ }^{8}$ Jennifer Fluri, 'Armored Peacocks and Proxy Bodies : Gender Geopolitics in Aid / Development Spaces of Afghanistan,' Gender, Place \& Culture: A Journal of Feminist Geography 18, no. 4 (2011), p. 525.

${ }^{9}$ Valentine M. Moghadam, 'Patriarchy in Transition: Women and the Changing Family in the Middle East,' Journal of Comparitive Family Studies 35, no. 2 (2004): 137-62.

${ }^{10}$ See Lila Abu-Lughod, 'Do Muslim Women Really Need Saving? Anthropological Reflections on Cultural Relativism and Its Others,' American Anthropologist 104, no. 3 (2002): 783-90; Julie Billaud, 'The Making of Modern Afghanistan: Reconstruction, Transnational Governance and Gender Politics in the New Islamic Republic,' Anthropology of the Middle East 7, no. 1 (2012): 18-37; Michaele L. Ferguson, "'W" Stands for Women: Feminism and Security Rhetoric in the Post-9/11 Bush Administration,' Politics \& Gender 1, no. 1 (2005): 9-38

${ }^{11}$ McLeod, 'A Feminist Approach to Hybridity'.

12 Jenny H Peterson, 'A Conceptual Unpacking Of Hybridity: Accounting For Notions Of Power, Politics And Progress In Analyses Of Aid-Driven Interfaces,' Journal of Peacebuilding \& Development 7, no. 2 (2012), 15.
} 
groupings mitigates against that critique. Illustrating this, Julian et al. in this special issue elucidate the possibilities for a feminist-inspired methodological engagement with the diversity of situated knowledges articulated in 'local' spaces, ${ }^{13}$ while Kappler and Lemay-Hebert outline an approach based on the 'intersectionality of peace', in order to capture the complexity of power and privilege which are layered, cross-cutting and relational within particular contexts. ${ }^{14}$

This article makes a contribution to both CPS and feminist peace and conflict studies. It builds on the pioneering work of scholars such as Roger Mac Ginty and Oliver Richmond, ${ }^{15}$ whose work on hybridity helped to reframe the debates around the liberal peace paradigm, by deploying these ideas in feminist terms and through the prism of certain gendered experiences of Afghanistan. It uses original interview data to unpack the unexplored concept of the 'third gender' as a site of embodied everyday experience in peacebuilding and thus contributes to a growing feminist literature on the complexities of (post-)conflict ecosystems and the ways that race, gender and power intersect to produce particular systems of privilege, distance and difference in the 'post-war moment'. ${ }^{16}$

I focus on Afghanistan because it was during my research into the gendered practices of intervention and peacebuilding there that I came across the notion of the 'third gender'. Moreover, because of the centring of gender in the rhetoric and representation of post-conflict Afghanistan, it is a very important context in which to explore how gender threads through the everyday praxis of peacebuilding. However, as I suggest in my conclusion, there is room for fruitful further research into

\footnotetext{
${ }^{13}$ Rachel Julian, Berit Bliesemann de Guevara and Robin Redhead 'From Expert to Experiential Knowledge: Exploring the Inclusion of Local Experiences in Understanding Violence in Conflict'

${ }^{14}$ Lemay-Hebert and Kappler 'From Power-Blind Binaries to the Intersectionality of Peace: Connecting Feminism and Critical Peace and Conflict Studies'

15 See for example Roger Mac Ginty, "Hybrid Peace: The Interaction Between Top-Down and Bottom-Up Peace," Security Dialogue 41, no. 4 (2010): 391-412; Oliver Richmond, "Becoming Liberal, Unbecoming Liberalism: Liberal-Local Hybridity via the Everyday as a Response to the Paradoxes of Liberal Peacebuilding," Journal of Intervention and Statebuilding 3, no. 3 (2009): 324-44.

${ }^{16}$ See for example Cynthia Cockburn and Dubravka Zarkov, eds., The Post-War Moment: Militaries, Masculinities and International Peacekeeping (London: Lawrence and Wishart, 2002); Claire Duncanson, Gender and Peacebuilding (Cambridge, Malden: Polity Press, 2016); Gina Heathcote and Dianne Otto, eds., Rethinking Peacekeeping, Gender Equality and Collective Security (Palgrave Macmillan, 2014); Paul Higate and Marsha Henry, Insecure Spaces: Peacekeeping, Power and Performance in Haiti, Kosovo and Liberia (London, New York: Zed Books, 2009).
} 
other contexts.

The article progresses in three parts; I develop the framework of gendered hybridity further and outline the notion of the 'third gender' and its use in Afghanistan, I then use my interview data to explore how the 'third gender' concept functioned as one kind of embodied, performed hybridity; a manifestation of friction and hybridity in the lived experiences of international peacebuilding actors. Embodiment here refers to the centrality of the body as a site of identification and experience, ${ }^{17}$ while performance indicates those behaviours enacted to conform to societal expectations in particular ways. In the third and final section of the article I unpack what the 'third gender' as an idea can tell us about the gendered and racialised ordering of the liberal peace paradigm in Afghanistan. Before I move to the body of the article, I will outline a few points on my methodology.

My methodological approach is based on original interview data from semi-structured interviews. While I focus on and cite from six interviewees in this article, these interviews are part of a wider research project on Afghanistan which included further semi- and un-structured conversations (I have interviewed 41 participants formally and others outside of those cited here also mentioned the 'third gender' term and similar ideas), as well as a visit to Afghanistan in 2014. During my research I interviewed civil society and military actors who are working or had worked in Afghanistan, both Afghans and 'internationals'. Those mentioned in this article are German, American, Australian, and Afghan-Canadian and are all female. One cited interview took place in person in Kabul in 2014, the rest were contacted via a closed online network for people living and working in, but largely not from Kabul, and took place via Skype in 2017. Those who easily identified with the 'third gender', or those who were referred to as doing so are described as 'international' in the sense that they did not identify as Afghan nationals and mostly worked for NGOs, IOs, donors, institutions such as the International

\footnotetext{
17 See Catherine Baker and Tarja Väyrynen in this special issue for further theorisation and expansion of the role of embodiment in feminist peace studies.
} 
Security Assistance Force (ISAF) etc. that involve actors, mandates and financing developed or originating outside of Afghanistan.

My focus on the 'third gender' comes from it being mentioned several times in interviews and while I make no claim to generalise for all female 'internationals' (especially given the number of participants cited), I infer from my interviewees' comments on its ubiquity that it was a common term and framework. My respondents referred to 'third sex' and 'third gender' interchangeably at points. I have settled on the consistent use of the term 'third gender' in this article because I am conducting a feminist analysis attuned to the operation of gender and because this categorisation was something social and performed, not implying biological difference. There is much more to be said here on the distinction between sex and gender and the productivity of the space between them that I do not have the scope to say, and it needs to be acknowledged that I also discuss the concept of the 'third gender' in one particular way, referencing women whose sexuality I do not engage with. There is a wealth of queer theory that deals much more fully with the complexities of non-binary sexualities and gender performativities which I overlook in this article due to restrictions of space and focus. ${ }^{18}$ However, my narrow and unusual engagement with the 'third gender' allows me to explore the nuances and ambiguities within certain lived experiences of hybridity and friction and thus contribute to scholarly work on peacebuilding and humanitarian spaces.

\section{A Feminist Approach to Hybridity}

Drawing on feminist scholarship, in particular Laura McLeod's work, I engage a feminist approach to hybridity in this article. This approach provides space for a 'textured' understanding of power relations between different actors and centers experience as an entry point. ${ }^{19}$ Doing this allows for two types of analytical shift; firstly, it allows for the muddying of our understanding of how power

\footnotetext{
${ }^{18}$ See for example William B. Turner, A Genealogy of Queer Theory, (Philadelphia: Temple University Press, 2000)

${ }^{19}$ McLeod, 'A Feminist Approach to Hybridity'.
} 
works in peacebuilding contexts and importantly, how it travels. Since it looks for nuance and change in power relations, a feminist approach to hybridity might pay close attention to the ways that nonlocal actors 'translocate their own positionalities (i.e. class, culture, gender and ethnicity/race)' to their peacebuilding context, ${ }^{20}$ As such it has parallels with Kappler and Lemay-Hebert's intersectionality of peace approach and can recognize how gendered power relations intersect with other kinds of difference and privilege differently at different sites, exploring the non-linear ways that power(/lessness) is carried from context to context while being shaped, perceived and felt on an everyday, situated level. For Kappler and Lemay-Hebert these nuances of power are better articulated outside of the concept of hybridity due to its dichotomizing tendencies. As per their critique, I am guilty of replicating the binary between 'international' and 'local' in this article for the purpose of analysis. However, I also illustrate that this binary is not clear-cut when we approach it from a feminist perspective and thus demonstrate that a feminist application of the concept of hybridity can contribute to an understanding of the relational and felt nature of power. Second, the centering of experience within the concept of hybridity requires us to engage with how it is lived out, embodied, remembered and represented. For instance, I am interested in how my respondents described their gendered feelings, experiences and perceptions. Even taking into consideration the so-called 'local' and 'everyday' turns in CPS, the concept of hybridity in peace research often still foregrounds collective, public or abstract phenomena such as cultures, institutions and norms (even if they are locally-based, or everyday ones). ${ }^{21} \mathrm{~A}$ feminist approach to hybridity, paying attention to the complexities of gender, directs us to different sites and ways of being such as the individual, the private, the lived and performed and the ambiguity of the everyday. A feminist approach to hybridity is interested in embodied experiences as forms of peace or conflict work in and off themselves which are taking place at the intersections of different kinds of privilege and marginalization, without losing track of the broader structural forces that shape conflict-affected lives and spaces. If, as Peterson

\footnotetext{
${ }^{20}$ Roger Mac Ginty and Gurchathen Sanghera, "Hybridity in Peacebuilding and Development: An Introduction,” Journal of Peacebuilding \& Development 7, no. 2 (2012), 3.

${ }^{21}$ Jonathan Goodhand, "Contested Boundaries: NGOs and Civil-military Relations in Afghanistan," Central Asian Survey 32, no. 3 (2013): 287-305; Mac Ginty, "Hybrid Peace: The Interaction Between Top-Down and Bottom-Up Peace."
} 
suggests:

[a]nalytically, it is the notion of the 'contact zone' (i.e. between local and external) and the creation of 'new forms' (i.e. non-liberal or post-liberal) that resonate most clearly in current usages of hybridity within the fields of peace and development studies, ${ }^{22}$

then feminist explorations of hybridity in this vein might look to the 'new forms' of gender identity, perception, performance and difference that intersect with other dynamics (race, status etc.) in the 'contact zone' of conflict-affected places. These new forms can be framed in terms of experience, imaginaries and the felt everyday, perhaps 'new' only in the sense of being perceived, constructed or experienced as such.

As I outline more fully in the following sections, I see the 'third gender' in the context of international usage in Afghanistan as a kind of embodied, performed hybridity. The Afghan context and perceived gendered expectations in Afghanistan are mixed with the bodies, behaviours and expectations of international women to form something that contains gendered elements of masculinity, femininity, the 'illiberal' and the liberal social orders.

Hybridity, understood through feminist lenses, and in line with the original post-colonial understanding of the term, ${ }^{23}$ is potentially disruptive to the hegemonic project of the liberal peace because it destabilizes decontextualised projects and their universal templates. ${ }^{24} \mathrm{I}$ argue here that, with the addition of a feminist lens, it also disrupts the very framework of the 'liberal' as it takes account of the multiplicities of gendered hierarchies that cut through both liberal and non-liberal social orders.

Friction in peacebuilding literature is a term often applied to policy implementation, it points to distinction between expectations and reality, between an idea and its actualization in praxis. Friction in peace literature focuses on 'conflictual encounters' between external ideas or norms and 'local'

\footnotetext{
22 Peterson, 'A Conceptual Unpacking of Hybridity', 11

23 Ibid.,

${ }^{24}$ See also Kappler and Lemay-Hebert in this special issue.
} 
ones, it is similar to hybridity in that it is about the drawing together of different actors/norms but it focuses on the process of contestation. ${ }^{25}$ Because friction is attuned to the operation of power, agency and struggle, it is again well aligned with feminist thinking. While I suggest that the 'third gender' is a hybridity-infused framework, I also argue that it allows us to see processes; sites of friction within gendered experiences of the peacebuilding paradigm. By this I mean moments where embodied identities are being pulled in different directions, and divergent expectational parameters are coming up against each other.

It is important to recognise that I am using the notion(s) of hybridity (and friction) analytically in a specific way here. I am suggesting that it is productive to view the notion of the 'third gender' as a hybridized identity framework, which draws a 'liberal' understanding of gender-women as professional and societal equals- into confluence with an 'illiberal' one - women who behave as equals are masculinised, and not real women but something else. In this way it is possible to explore the nuance and complexity that emerges from the lived, gendered, racialised experience of a certain kind of hybridity. To be clear, I am not attempting to suggest that this is anything other than one way to frame and deploy the analytical concept of hybridity in feminist terms, I am also not reifying the idea that liberalism is actually conducive to gender-equality, that Afghan women are actually passive/always silenced or that Afghanistan is only ever patriarchal, but rather using this notion of the 'third gender' as a window through which to explore some elements of the operation of gender within the Afghan liberal peace project.

\section{The 'Third Gender' in Afghanistan}

The third sex or gender has mostly been a way to describe a person or people who transcend sex and/or gender-based dimorphism. This happens in lots of ways, through genitalia, hormonal make-up, sexuality, and performativity that do not fit neatly into the sex or gender-based distinctions between

\footnotetext{
${ }^{25}$ Björkdahl and Höglund, 'Precarious Peacebuilding', 292
} 
male(/masculinity) and female(/femininity). There are historical associations between citizenship, colonialism, race and the queer and/or non-binary body. As Cynthia Weber points out, the depiction of a savage, racialised Other as sexualised, deviant and 'homosexual' actually 'played a role in licensing Victorian sovereign states to subject entire colonialized populations to imperial rule' ${ }^{26}$ Queerness is also a trope deployed in Orientalist framings of a racialised Other, including in western media depictions of Afghanistan. ${ }^{27}$ Those such as hermaphrodites, queer individuals and others who have been associated with the term 'third gender' have often faced discrimination, as the limits of what constitute acceptable gender behaviours are policed within different social worlds. ${ }^{28}$ As late as the latter part of the twentieth century, children who were born in the UK and elsewhere who fell outside of the gender binary for various reasons were medically reassigned without their consent. ${ }^{29}$ Thus, internationals using this term in Afghanistan are drawing, probably unconsciously, on a trajectory of meaning which situates them in a wider history of both subversive sexuality and imperial as well as medical violence. They call to action a term which indicates non-binary liberation from gendered hetronormativity as well as suppression and discrimination, thus illustrating the way that fragments of meaning travel, carrying aspects of their original significance while gaining significance anew as they become remoulded through embodied and discursive use.

While a full discussion of the history and use of the 'third gender' concept falls outside of the scope of this article, it is important to note that both biological and social aspects of sex and gender exist on a spectrum whereby a simple dichotomy between male/masculine and female/feminine is clearly false, yet feminist scholarship consistently demonstrates that this dichotomy structures multiple facets of our world, from language to war. ${ }^{30}$ Thus the idea of a 'third gender' potentially contests the power-

\footnotetext{
${ }^{26}$ Weber, 'Queer Intellectual Curiosity as International Relations Method : Developing Queer International Relations Theoretical and Methodological Frameworks,' International Studies Quarterly 60, no. 1 (2016), 12. ${ }^{27}$ See Nivi Manchanda, 'Queering the Pashtun: Afghan Sexuality in the Homo-nationalist Imaginary', Third World Quarterly, 36 no. 1 (2015): 130-146.

${ }^{28}$ See Jake Scobey-Thal ‘Third Gender: A Short History’, Foreign Affairs, 30 June 2014, https://foreignpolicy.com/2014/06/30/third-gender-a-short-history/, last accessed 17/09/18.

${ }^{29}$ See Colette Bernhardt, 'The Third Sex: The Truth about Gender Ambiguity' The Independent 20 March 2010 , https://www.independent.co.uk/life-style/health-and-families/features/the-third-sex-the-truth-about-genderambiguity-1922816.html, last accessed 17/09/18.

${ }^{30}$ See for example Carol Cohn, 'Sex and Death in the Rational World of Defense Intellectuals,' Signs: Journal of Women in Culture and Society 12, no. 4 (1987): 687-718,; Cynthia Cockburn, 'Gender Relations as Causal in Militarization and War: A Feminist Standpoint,' in Making Gender, Making War: Violence, Military and
} 
laden gender dichotomy between male and female, but, as I demonstrate in this article, could equally be understood to reinforce that dichotomy as well as other kinds of difference. During my research, I discovered that the 'third gender' was being used in an unexpected way by international women and those who spoke about them. On respondent described it like this:

Women there, foreign women, are kind of this third gender for Afghans, especially Afghan men. From an Afghan male perspective, I'm generalising, but in general there are men and foreign men, and then there are Afghan women and then there are foreign women. For them foreign women are just sort of this like strange amalgamation of woman and man (Anna, American Education worker)

Within the notion of the 'third gender' in Afghanistan was the idea that foreign women were not entirely women but not men either. It contained a complex uncertainty that was both gendered and racialised. ${ }^{31}$ The interaction between some concept of the 'foreign' and some concept of the 'female' played out as a site of friction in which 'porous boundaries' ${ }^{32}$ between different notions of woman were marked by distinctions between foreign and local bodies in terms of differential freedom and access. Kate exemplified this well in the following comments: '[p]eople talk a lot about foreign women being like the third sex. I don't really like the analogy but there is certainly things that you can do, that Afghan women can't do ...' (Kate, Australian research consultant).

Liberal citizenship (not specific to bodies of a particular race) is a citizenship association with countries - especially in the 'west' - that identify as liberal democracies with gender-equitable value systems (in theory). Liberal citizenship creates a sense of confusion and unease around the notion of 'woman' in contexts understood as illiberal. It bestows expectations around how women can behave, their capacity to enter the public sphere and at least a nominal sense of individual professional

Peacekeeping Practices, ed. Annica Kronsell and Erica Svedberg, Kindle (London, New York: Routledge, 2012), 19-34; Cynthia Enloe, Bananas, Beaches, and Bases: Making Feminist Sense of International Politics (Berkeley: University of California Press, 1989).

${ }^{31}$ Hannah Partis-Jennings, 'The (In)security of Gender in Afghanistan's Peacebuilding Project: Hybridity and Affect' International Feminist Journal of Politics 19, no. 4 (2017): 411-425

${ }^{32}$ Niels Nagelhus Schia and John Karlsrud, "'Where the Rubber Meets the Road": Friction Sites and LocalLevel Peacebuilding in Haiti, Liberia and South Sudan,' International Peacekeeping 20, no. 2 (2013), 246. 
authority, equality and freedom. What comes up continually within the notion of the 'third gender', is the disruption but not dispersal of these expectations, the uneasy in-between-ness that comes with bringing ideas about liberal and illiberal womanhood into confluence.

Speaking about needing to get a tyre fixed on her motorbike, Eva said:

[A]n Afghan female could never do that, and you had a huge amount of freedoms and you became kind of more conscious about this freedom, because you had a direct comparison so to speak (Eva, German ISAF civilian personnel).

Foreign womanhood here is understood through a conceptualisation of agency and freedom that becomes more significant as against an apparently 'direct comparison' with non-agency and unfreedom. Respondents described their gendered identities as constituted by a process of negotiation due to their hybridity-infused experience as females who were not, in their understanding, fully feminised in the Afghan context. Luise illustrated that the very ownership of a gender identity became context-dependent:

[B]ecause my socialisation is German, or European, I would certainly identify, if I would identify, I would identify as a woman, like I would never say I identify as third gender. I identify as third gender in the Afghan context if that makes sense (Luise, German UN worker).

Luise's way of framing her gender identity as context-specific in Afghanistan speaks to the complex 'performative infrastructure' ${ }^{33}$ involved in simply being a foreign female, the understanding that gender was fluid and contingent for internationals. Equally, there is again an implicit suggestion that by comparison, it was not so fluid and contingent for Afghans. Eva stated that: 'the Afghans see you... as a female of course but more like a third gender ...not ... their Afghan females' (Eva, German ISAF civilian personnel) implying a knowable and static femininity against which the foreign woman was defined.

\footnotetext{
${ }^{33}$ Luiza Bialasiewicz et al., 'Performing Security: The Imaginative Geographies of Current US Strategy,' Political Geography 26, no. 4 (2007), 415.
} 
In terms of the ubiquity of the 'third gender' as a discursive currency, Luise recounted that she was told about the concept almost as soon as she arrived in Afghanistan (Luise, German UN worker), while Eva explained its frequent use in experiential terms - 'you take it up as a notion which makes sense to describe the actual experience' Eva, German ISAF civilian personnel, emphasis added). This experience was always a mixing together of the 'local' context/gender norms with the 'international' body/gendered expectations that was felt and performed though it did not necessarily imply a substantial change in actual behaviour:

So that I guess what is behind this notion of the third gender that it is, it really provides you with a way to behave or feel very freely, you don't necessarily engage in seriously strange, different behaviour than normally, it is just this feeling that you are really not bound by the normal society rules in a way ... That really is kind of strange [sic] (Eva, German ISAF civilian worker).

Eva positions the 'third gender' and her life in Afghanistan as one that offered felt liberation from the constraints of gender norms and this offers up a view of the liberal peace paradigm as a space of exception, especially for bodies marked by liberal citizenship. The 'third gender' framework frees the international woman, allowing a sense of liberation from gendered expectations and adherence to gender binaries yet, equally, this is only made possible when the binary itself can be understood to originate with Afghan socio-cultural norms. The Afghan gender order can be transcended by the privilege of liberal citizenship yet it also shapes the very idea of womanhood in the peacebuilding context, arguably crafting the idea of a 'new form' in the hybrid space of the 'contact zone', ${ }^{34}$ one that is felt and lived.

\section{Unpacking the 'Third Gender'}

While hybridity and friction focus on the dynamics between the 'international' and the 'local', this section unpacks what the 'third gender' can tell us about peacebuilding and explores how a feminist

\footnotetext{
${ }^{34}$ Peterson, 'A Conceptual Unpacking Of Hybridity', 11
} 
engagement with hybridity can capture the shifting and situated intersectional interactions between elements of race, status, citizenship and gender. For instance, the experience of Afghan-Canadian respondents demonstrated the ways that 'womanhood' is policed and navigated through, alongside and within the boundaries of racial expectations in varied ways within the peacebuilding context.

Safia, an Afghan-Canadian IO worker, described the negotiated nature of her everyday life: 'I'm trying to fit in, I don't fit in, but then sometimes I don't really want to fit in.' She talked about the way some colleagues would assign her 'local' status. Yet she felt her identity was in fact a complicated and hybridised one: 'I think that the way they see it is I'm just a local I can go hang out with the locals, but I work here as an international'. There is a certain agency evidenced in her identity framework, sometimes she has no desire to fit in' with either 'local' or 'international' identity categories.

Yet Safia also spoke to the friction at work within her performance as an 'international' whose body (in the eyes of others) tied her to different expectations than those placed on foreign bodies. She gave the example of how foreign-educated Afghan men reacted to her dismissively, including making 'weird comments' about the legitimacy of her $\mathrm{PhD}$ (suggesting that it might be fake), insisting on 'putting an Afghan label' on her, resenting her salary, and having difficulty accepting that a woman who appeared physically as Afghan was not easily categorised according to their gendered expectations: 'because they are men, and they are foreign-educated but they are still Afghan, I don't know, I feel I am sensing more of an issue with that, the way that I am not actually an Afghan woman, but I look like it' (Safia, Afghan-Canadian IO worker). Her Afghan-ness is bound to her in a bodily way and she somehow ought to perform Afghan femininity in line with her bodily image, but she is equally tied to a sense of her own foreign-ness which also shapes her gendered identity and performative expectations of her work and lifestyle. 
Safia talked about the 'third gender' as something she could see and hear about among foreigners, but not fully access. Here, she is talking about noticing others (foreign women) fitting into the category of the 'third gender' in her work place:

I remember I read this article about this woman who said you know she was allowed to pass through the genders whether it was male or female, through the different spaces. And I notice it you know every day at work, I literally notice it every day (Safia, Afghan-Canadian IO worker).

When I asked her if she was ever understood through the prism of the 'third gender' she stated: 'it can be true for me - if I play that card. If I completely deny that Afghan connection, if I say that I don't speak the local languages'. Her words illustrate that this category of the 'third gender' for her required a performative rejection of the 'local' and locally situated knowledge.

Masha, another Afghan-Canadian respondent, also illustrated that the elements of gendered identity which shaped her experience were often defined externally and that she experienced a friction between expectations and realities which was deeply frustrating. She articulated this sense of frustration to me directly: 'so I kind of want to sometimes just scream and say: 'well if I'm foreign then let me do whatever the hell I want, and if I'm not, stop calling me foreign'" (Masha, AfghanCanadian NGO programme director). Thus, these participants who were both 'local' and 'international' (Canadian), by birth, did not associate themselves easily with the 'third gender' framework because their race and 'localness' tethered their gender differently, producing particular categories of difference and navigation within the peacebuilding paradigm.

Importantly, the categorisation of the 'third gender' seems to participate in the construction and reproduction of certain racialised ideas about Afghan men and Afghan women/femininity. It implies that Afghans (especially men) are so deeply wedded to their understanding of women as subordinate, that in order to cope with women who, by virtue of their relative wealth, status and international 
origins could not be subordinated, they must see them as not women. There is a racialised homogenisation of the Afghan male and social order implicit in this categorisation, perhaps indicative of what one respondent described as 'an international prejudice against the Afghan people and them not being able to actually listen to intelligent people [who were female]' [sic] (Luise, German UN worker). This traces the idea, as articulated by Nivi Manchanda, that the 'Afghan man' is framed as always already 'monstrously misogynistic' ${ }^{35}$

Thus in abstracted terms, this idea of the 'third gender' in Afghanistan speaks to the crashing together of a liberal order in which cultural (if not always actual) gender equality is a pillar of market democracy and individualism, ${ }^{36}$ with that which is understood to be an illiberal order, marked by inequality and lacking in progressive norms.$^{37}$ As many feminist scholars have pointed out in relation to the intervention in Afghanistan, this crashing together is rendered intelligible by negating Afghan women's agential subjectivity, collapsing them into a monolithic victim, foil to the patriarchal, 'monstrously misogynistic' Afghan male as well as the liberated 'western' woman. ${ }^{38}$ Thus the 'third gender' as a means of (self-)identifying the foreign female body is at once a judgement upon the capacity of Afghan men to fully accept a gender order beyond their own, and a positioning of Afghan women as the truly feminised in this context, where feminisation is equated to passivity and victimhood. Eva stated that as a member of the 'third gender':

you are different to the Afghan man than an Afghan female would be who is of course very protected and very seen in that Afghan traditional kind of style in a way, because you are open, you are outspoken, I think they are respecting you [sic](Eva, German ISAF civilian personnel).

\footnotetext{
${ }^{35}$ Manchanda, 'Queering the Pashtun', 130

${ }^{36}$ Nancy Fraser, 'Feminism, Capitalism and The Cunning of History,' New Left Review 56, no. March/April (2009): 97-117.

${ }^{37}$ Julie Billaud, 'The Making of Modern Afghanistan: Reconstruction, Transnational Governance and Gender Politics in the New Islamic Republic,' Anthropology of the Middle East 7, no. 1 (2012): 18-37.

${ }^{38}$ Ferguson, 'W' Stands for Women'; Keally McBride and Annick T. R. Wibben, 'The Gendering of Counterinsurgency in Afghanistan,' Humanity: An International Journal of Human Rights, Humanitarianism, and Development 3, no. 2 (2012): 199-215.
} 
She indicates a distinction between 'traditional' and liberal values, where the latter allows for respect and the former is marked by voicelessness. Again, as so often, gender here does not manifest as a relation of power that exists in a vacuum, but rather functions as 'part of the processes that also constitute class and race as well as other lines of demarcation and domination'. ${ }^{39}$ In Eva's words, Afghan women in Afghanistan are truly female, and the implication is that they are truly subordinated, so that subordination and true femininity are somehow linked, while having freedom, authority and access in Afghanistan means a performative negation of subordination/femininity. Eva did not particularly want to generalize, and she was self-reflexively awkward about using terms such as 'their females' to describe Afghan women, and yet found this language her only mechanism to explain her experiences. Arguably however, the 'third gender' as a framework of meaning is made possible in this context because of the circulation of the troubling idea that 'brown men' are somehow backward, traditional and oppressive, and 'brown women' are silenced and powerless. ${ }^{40}$

However, to suggest that the 'third gender' is purely based on a racialised assumption of Afghan patriarchal conditions would be to fail to capture the complex site of friction and hybridity that the term entails. The 'third gender' is also a contradictory space that demonstrates simultaneously a pulling away from the restraints placed upon the (liberal) female body and equally a reaffirmation of its subordination. To illustrate the first dimension, respondents would point to the fluidity and potential afforded by the 'third gender' categorisation. Luise stated that: 'because I feel like every human being should be able to do what they want to do, and by falling in-between being a man and being an Afghan woman you can actually'. She suggested increased possibilities in her work as a result: 'ultimately, when it comes to the work, I actually think as that third gender you actually have access... you are a lot better equipped to talk to both parts of society' (Luise, German UN worker).

\footnotetext{
${ }^{39}$ Joan Acker, 'Gendering Organisational Theory,' in Gendering Organisational Theory, ed. A.J. Mills and P. Tancred (Thousand Oaks, CA: Sage Press, 1992.), 567.

${ }^{40}$ Nicola Pratt and Sophie Richter-Devroe, "Critically Examining UNSCR 1325 on Women, Peace and Security," International Feminist Journal of Politics 13, no. 4 (December 2011): 489-503.
} 
The 'third gender' could function as a space of agency, where the restrictions of feminisation could be detached from the female body and discarded, a de-gendering performance which opens up possibilities for access and enjoyment without any loss or distancing from the sexed female body itself. There is a sense of sexual liberation associated with it, as well as an increased power, voice and authority. One respondent described how, despite never learning to drive in the UK or Germany, she had used a motorbike to see the city of Kabul when she was based there, allowing her to be independent and adventurous. She went on to say:

when I think about the time in Afghanistan, a female in Afghanistan, working for the military, living in a military installation in a country which is patriarchal to the core, and I still felt the most free in my life (Eva, German ISAF civilian personnel, emphasis added).

Another international described how some women (like some men) would take off their wedding rings as soon as they entered Afghan airspace (Anna, American education worker) implying a space of social of exceptionalism. Most respondents described the respect they were shown by Afghans in the workplace particularly. This first dimension is thus indicative of a fascinating agency, freedom, exceptionalism and respect bestowed upon the female international body in this conflict-affected context. The 'third gender' thus indicates a performative space in which liberation could be enacted despite the huge variety of restrictions at work in Afghanistan in different ways; seen like this it marks a site of 'liberal' values in the embodied and ideational sense, where women could access a 'masculine' domain of power and authority but without being masculinized according to their own social standards (they are not seen as men). Moreover, for some, it could offer a sense of freedom in relation to home or a 'western' context: ‘you felt very free from even values, stuff, behaviour you would usually, which is expected from you in a western society as normal kind of behaviour' (Eva, German ISAF civilian personnel). This demonstrates the way the lived experience of the liberal peace constructs a space and imaginary of exception; a shift in and release from certain normative parameters and behavioural expectations. 
In this space of exception international women could leverage their hybrid gender identity framework, seeking to transcend boundaries and facilitate work they recognised to be important in ways that promoted inclusivity. As Luise suggested:

$[\mathrm{I}] \mathrm{t}$ is possible to talk to men, but it is also possible to talk to women, and especially when you work on peace and if you talk about it in terms of inclusive peace, if you want to build an inclusive peace process actually as a woman you are a lot better equipped to talk to both parts of society, in most cases (Luise, German UN worker).

By carefully retaining both woman-hood and access/authority, my respondents could try to situate themselves as culturally dissonant but respectful guests helping to link together different strands of the Afghan social order and ensure that Afghan women's voices were heard.

The second dimension however, is quite different. Respondents who identified with the categorisation of the 'third gender' in Afghanistan also pointed to their experiences of hyper-sexualisation or patriarchal expectations within the international domains. Eva talked about the way that international men could view their female counterparts as sexually available and subordinate: 'the perception changes to "oh these women in Afghanistan, who are working here and who are here just for the fun and the wild parties and we don't have to take them really equal"'. She suggested a distinct lack of equality in this space: 'as a female, all of the kind of bad stuff we had before emancipation kind of kicks in. You are kind of not so much an equal as you are in the UK or Germany or any kind of normal environment, it is really different' [sic] (Eva, German ISAF civilian personnel).

Moreover, the backdrop of a tense and threatening conflict-affected country, in which internationals and their organisations are frequent targets of attacks carried out by the Taliban or Islamic State 
affiliates, renders a masculinised security environment commonsensical ${ }^{41}$ In particular, private military security contractors are emblems of masculinised security practice which centres on weapons, stoicism and a constancy of risk. ${ }^{42}$ Safia described how the attitude of the private security personnel (who hold significant authority as harbingers of security) in her various places of work 'was very much like "I've got a gun, I've got a machine-gun", full display of masculinity or sort of the militarised version of it... it is all about violence, guns and you hear the stories about how tough they are... very macho, very macho' (Safia, Afghan-Canadian IO worker, emphasis added). Certain respondents reported a distinctly gendered experience of male security personnel, contrasting the freedom and sense of liberation discussed earlier.

Luise posited a kind of gendered governmentality in her everyday life. She described 'international men being really worried about my personal life, which I do think is related to my gender', particularly a situation where

one of the security officers at a party and he is the guy that is responsible for tracking where we are most of the time. He said ..."I know you stayed over at the US embassy, do you have a boyfriend there?"

She told me that many women faced inappropriate, searching questions such as this, somehow framed as tied to their security (where men did not) and a lack of any faith in their ability to look after themselves, despite, as in Luise's case, greater knowledge of Kabul than the security personnel themselves. She commented that because of this gendered treatment: 'I feel like I am really in prison' as well as noting that 'in terms of discrimination, and structural discrimination, a lot of the discrimination against women actually comes from the international community'. (Luise, German UN worker)

\footnotetext{
${ }^{41}$ Mark Duffield, 'Risk Management and the Bunkering of the Aid Industry,' Development Dialogue 58 (2012): 21-36; Róisín Shannon, 'Playing with Principles in an Era of Securitized Aid : Negotiating Humanitarian Space in Post-9/11 Afghanistan,' Progress in Development Studies 9, no. 1 (2009): 15-36.

${ }^{42}$ Partis-Jennings Hybridity and Affect
} 
Here then, once again, the trope of the 'third gender' manifests as a duality whereby these women are truly free of gendered constraints only where there is an illiberal Other against which to be defined. The abstention from the constraints of femininity and the association to almost masculinity that comes with the possession of a foreign body is temporally and spatially situated. It is only in a particular place at a particular time that womanhood can be abandoned and only if one's body conforms to liberal subjectivity. Without the foil of the vague and static subordinated Afghan woman, or the unshakably traditional Afghan male, the international female body slips into a site upon which to map sexualisation and over which to seek control.

\section{Conclusions}

Read, focusing on aid worker memoires articulates that:

[t]he ways in which female aid workers narrate their experiences of the spaces of humanitarianism offer an important contribution to the construction and maintenance of a distinctly humanitarian social imaginary, which highlights the complex and intersecting hierarchies of gender, race, class, nationality, and age that are deeply embedded in humanitarian practices. ${ }^{43}$

With a similar understanding in mind I have suggested in this article that within this one embodied, experiential label of the 'third gender' are bound different uncertainties about what it means to be a foreign female in a peacebuilding context, as well as different kinds of pre-knowledge and perception about how Afghan men view women. ${ }^{44}$ The category of the 'third gender' does not fundamentally change the sexual identity of women, but instead collapses their race and international status onto their gender in particular ways; ways that are rendered intelligible only in relation to specific understandings of the Afghan context - it can encompass the dualities of freedom and restraint,

\footnotetext{
${ }^{43}$ Read, 'Embodying Difference', 2.

${ }^{44}$ Partis-Jennings, 'Hybridity and Affect'
} 
empowerment and disempowerment.

What is clear, and a contribution this article to the wider liberal peace scholarship, is that sites of hybridity, friction and the everyday mixing together of liberal/'international' ideas, expectations and bodies with 'local' ones are only fully elucidated by looking at gender identities. Gendered expectations weigh upon different bodies differently and shape different experiences of peacebuilding in particular ways, mapped and ossified through routine behaviours. ${ }^{45}$ The 'third gender' as a category is unstable, it is both and neither, in-between and something else. Yet arguably it is dominant because it is unstable, as it speaks to the constancy of hybridity and friction in the 'liberal' order and its inability to create identity or meaning without reference to the 'illiberal' Other. In being always already in-between a perception of Afghan 'tradition' and expectation of liberal 'modernity' the female body and its meaning is suspended, kept uncertain and unstable. Moreover, that uncertainty stuck to and shaped experiences, and was generated by the affective sensation of difference, of liberal rights and freedoms and of the racialised physical, psychological and everyday distinctions made within liberal peacebuilding between international and Afghan bodies. ${ }^{46}$

The 'third gender' and the friction between and within gender orders that it signals illustrates the work that individual women do to try to navigate their gender and the (dis)advantages it implies, in ways that are acceptable to their perceived context. They can self-negate as 'typical' 'females' by selfidentifying with or accepting or embracing a (temporary and situated) distancing from woman-hood in service of non-disruption, to protect their work and illustrate respect. Therefore, while the category of the 'third gender' is problematic, it echoes elements of relational approach to peace described by Tarja Väyrynen in this issue in which the Other (and their perspective) is acknowledged and accommodated. ${ }^{47}$ It is also potentially indicative of what Laura Shepherd might call 'hopefulness' in conflict-affected spaces, a desire for compromise on multiple sides and a willingness or attempt to

\footnotetext{
${ }^{45}$ See Judith Butler, Gender Trouble: Feminism and the Subversion of Identity, Routledge, Anniversar (New York, Oxon, 1999).

${ }^{46}$ See Jennifer Fluri, “'Foreign Passports Only': Geographies of (Post)Conflict Work in Kabul, Afghanistan," Annals of the Association of American Geographers 99, no. 5 (2009): 986-94.

${ }^{47}$ Tarja Väyrynen 'Mundane Peace and the Politics of Vulnerability: A Nonsolid Feminist Research Agenda'
} 
adapt to social structures without excessive imposition, ${ }^{48}$ and this element of the 'third gender' merits further study.

While it falls outside of the scope of this article to generalise to other contexts, or to investigate the appearance of the term 'third gender' used in similar ways outside of Afghanistan, I suggest that the insights I gain from exploring the Afghan context are likely to also map onto other conflict-affected spaces. Róisín Read's work demonstrates that some of the core dynamics that I explore here - such as distinction from 'local' populations, in-betweenness and the performance of gender roles by female humanitarians in very specific and negotiated ways - manifest in other contexts as well. ${ }^{49}$ Similarly, further research into the differently racialised experiences within 'international' domains, Afghan men and women's perspectives on (and experiences of) the concept and other facets of analysis are necessary to fully understand the 'third gender' in Afghanistan.

However, and crucially, this article has demonstrated the importance of paying attention to gendered dynamics as a form of hybridity within the 'international' space, it has illustrated that this can elucidate nuance within gendered orders, demonstrating that, for instance, international women may perceive themselves as a kind of 'new form' in relation to an Afghan gender order which they believe cannot recognise them fully as women, while at the same time finding the so-called 'liberal' international gender order in Afghanistan to be the restrictive one in typically patriarchal ways. The liberal peace paradigm as a whole is characterised by contradiction and disjuncture, sites of slippage and hybridity ${ }^{50}$ and a feminist, gender-focused lens brings to the fore the deeply political nature of everyday encounters.

A feminist lens gives us the tools to explore how - as with the category of the 'third gender' at the micro-level - the existence of the liberal paradigm at the macro-level is dependent upon an 'illiberal'

\footnotetext{
${ }^{48}$ Laura J. Shepherd, 'The Road to (and from) 'Recovery': A Multidisciplinary Feminist Approach to Peacekeeping and Peacebuilding,' in Rethinking Peacekeeping, Gender Equality and Collective Security, ed. Gina Heathcote and Dianne Otto (Basinstoke and New York: Palgrave Macmillan, 2014): 99-117. ${ }^{49}$ Read, 'Embodying Difference'.

${ }^{50}$ Mac Ginty and Sanghera, 'Hybridity in Peacebuilding and Development'; O. P. Richmond, S. Kappler, and a. Bjorkdahl, 'The 'Field' in the Age of Intervention: Power, Legitimacy, and Authority Versus the 'Local,"' Millennium - Journal of International Studies, 2015, 1-22
} 
Other, which anchors it, and which, once deflated in significance, elucidates the instability and negotiation inherent within liberal ideas of progress and equality. Without a feminist engagement, we cannot grasp the full ambiguity and uncertainty of the 'liberal' order itself, nor exactly how it fragments, pulls-apart and reforms when it encounters different contexts, and this, I suggest, is vital if we want to understand how peace work feels, is lived, and what it might produce. 